\title{
Underlying the triple burden effects on women educationists due to COVID-19
}

\author{
Pallavi Dogra $^{1}$ (D) Arun Kaushal ${ }^{1}$
}

Received: 24 January 2021 / Accepted: 17 June 2021 / Published online: 16 July 2021

(C) The Author(s), under exclusive licence to Springer Science+Business Media, LLC, part of Springer Nature 2021

\begin{abstract}
COVID-19 causes a pandemic situation that increased the paid or unpaid responsibilities (home and job) on women and brought significant changes in their lifestyle, resulting in psychological and emotional stress. This paper draws attention to the triple burden on the women during this time when certain roles are supposed to be performed by the women regardless she is employed or homemaker. The paper highlights the challenges faced by women educationists in making themselves comfortable with the work-life balance with emerging challenges such as new technologybased innovative teaching methods and various learning software's, apps, platforms, etc.. The paper employs in-depth interviews of teachers belonging to three categories i.e. primary, secondary, and higher education. The findings reported that female teachers agreed that pandemic had affected their daily life schedule. This leaves a deep effect on their mental and psychological health due to multiple attentions they pay towards home management, child \& elders extra care, challenges due to work from home pattern of organizations, increased attention to students due to online teaching, etc. The paper presents the implications for the society and government to understand the women's pressure so that a happy and satisfied life is there for all with no gender discrimination.
\end{abstract}

Keywords Pandemic $\cdot$ COVID-19 $\cdot$ Teachers · Education · Virtual platform · Gender biasness

Pallavi Dogra

pallavi.dogra.123@gmail.com

Arun Kaushal

arun.kaushal@gla.ac.in

1 Lovely Professional University, Phagwara, India 


\section{Introduction}

The corona-virus outbreak has affected the world lifestyle for both childhood and adulthood (Dunton et al., 2020; Shaukat et al., 2020), resulting in the sedentary lifestyle of the world population (Chen et al., 2020). Corona-virus spread measures followed by various governments includes social distancing, lockdowns, isolation, or quarantine for infected people have brought significant changes in the habits of workers and students (Brancaccio et al., 2021). Institutions active in all segments have changed their policies and working culture. They have given more liberty to their employees to make adjustments in their daily schedules and adopt "work from home (WFH)" (Prasad et al., 2020). During the first wave of covid19 spread, 30\% of Americans shifted to work from home option, 10\% were fired as reported by the National Bureau of Economic Research. Similarly, Accenture has moved over $60 \%$ of its employees to WFH in India and the Philippines (Sangani, 2020). Apart from IT, all the sectors which include healthcare, research, and development, education sectors that can be managed without physical presence are forced to accept the WFH option (Prasad et al., 2020).

Corona-virus made the entire education sector whether primary or higher education to shift from the face-to-face mode to online mode (Bao, 2020). The immediate online shift of the education industry added more stress and workload to female teachers who are struggling to maintain a work-life balance in the domain of teaching, research, home responsibilities, taking extra care during the pandemic, etc. (Houlden and Veletsianos, 2020). The elders staying at home also need extra care during this time, including proper diet and hygiene to fight against the risk of infection (Deshpande, 2020). The education sector that has transformed itself from offline mode to online mode brought new challenges such as technological anxiety and students' technological illiteracy (Brown, 2016). Due to the avalanche of workplace challenges when domestic chores, caretaking domains are disproportionately the question arises when both men and women are at home who will handle this. McLaren et al. (2020) opined that whether it is war, natural disaster, or pandemic, the women's vulnerabilities increases and acquiescence to additional burdens. Leckie (2016) and Momsen (2019) highlighted the societal gender difference affect women's social, economic, and political life. Most women reported facing deterioration in their well-being due to greater responsibilities in personal and professional life activities (Nawaz and McLaren 2016).

Many scholars such as Kaberia \& Muathe (2021); Shorey et al. (2021); Kumari et al. (2021); Liu et al. (2021); Dang and Nguyen (2021) have analyzed the effects of Covid-19 on women but very meager literature is available on the stress factors that affect the women educationists during the challenging times of pandemic. The study is unique in its style as it highlights the problems faced by female educationists belonging to an emerging economy i.e. India, where gender inequality already exists in education, healthcare, economic participation, decision making, etc. (Hooda, 2021). The differences among gender are observed to be embellished during the pandemic and across the globe. Uttar Pradesh has gender disparities in education, employment, and health implications for girls and women (Hebert 
et al. 2020). The author selected Uttar Pradesh, India for the data collection because development indicators reported the low status of females in the state (Priya et al., 2015). The National Family Health Survey-3 reported that $42 \%$ of women face sexual violence, $59 \%$ of women were married before 18 years, and women participation in the workflow is very low (17\%). The gender inequalities constitute a patriarchal society possessing triple bottom effects as one moves to the utteristic layers functional on the name of culture and tradition exacerbated specifically to one's gender, marital status, social and economic conditions. The geographical surroundings affect the strictness of its impact and its intensity gets deeper as one's moves from the urban to interior, remote and rural areas. Thus, examination of the triple bottom effects on women becomes more crucial in such a geographical location, where women's development is less.

The paper discussed the extra burden faced by women in their personal and professional life due to roles defined and expected by society. The study analyzed the female teacher's burden from three perspectives that need to be taken care of for the well-being of female teachers during pandemic times, so that satisfaction, prosperity, and happiness can be enhanced in their professional future. The first domain includes social and personal life that is affected due to increased household tasks due to multiple reasons including lockdown, house helper's suspension of services, increased expectations of family members, more focus on hygiene and sanitation conditions, and many more. The second domain includes the effect on professional life i.e. the employer expectation, increased work pressure due to online classes, challenges involved in the adoption of ICT techniques, etc. Further the effect on the financial component that is affected due to salary deduction, job layoffs, delay in salary payment, etc. The last perspective is the psychological and emotional effects on mental wellbeing due to critical time and the heartbreaking news due to the coronavirus and increased engagement with the organization and family affairs.

Our study contributes to the discipline of policymaking. This study delivers the psychological, social, financial, professional stress factors underlying female educationists who are coping with difficult and challenging times. This study is useful to the government bodies in understanding the stress level faced by women educationists during the time of novel COVID-19 so that they can plan to reduce stress and increase women's happiness and wellbeing.

\section{Literature review}

\subsection{Environment and social changes}

COVID-19 virus makes the world to adopt remote work or WFH concept to get saved themselves from the infectious risk of a mutated virus which is making its presence worldwide (Prasad et al., 2020). Various software and innovative tools such as "viewer, Splashtop, Microsoft remote desktop, zoom, Microsoft teams, and owlare" make this phenomenon easy and possible (Pinola, 2020). Several challenges such as technical literacy, the comfort of using these tools, overworking, bad health habits, distraction at home, etc. affect employee satisfaction (Wheatley, 2017). Apart 
from these challenges, social and family expectations from women are endless. Across the sphere including many countries and having various cultures and traditions, it is "SHE" who consistently carries the heaviest burden of expectation and responsibilities (McLaren et al. 2020, Lee et al. 2019; Nawaz and McLaren 2016). Social stigma can't alleviate the women to be free from the existing responsibilities (Moreno and Shaw 2018). The impact of additional and intensifying burdens on women can be long-lasting, which they may endure well beyond the resolution of the disaster itself.

\subsection{Personal life changes: Increased family obligations}

Moser (2012) in his gender analysis purposed that women's vulnerabilities at the time of the disaster, such as war, pandemic, natural calamities, and malnutrition are intensified (Bradshaw 2015). This is because increased responsibilities affect women completely where gender discrimination adds more complexity (McLaren et al. 2020). In India, women are bound to perform various roles and duties that include the children's care, their education, and household chores, etc. (Aryee et al., 2005; Ravindran and Baral, 2014). If there remains some incompleteness then blame is passed to the women. Gender egalitarianism is followed in western countries and male spouses help their wives by doing housework (House et al., 1999). Whereas in India, males doing domestic work perceived to be weak (Aycan, 2004), and females who fail to do motherly and wifely duties are often realized to feel guilty for this (Jost \& Banaji, 1994).

Government across the globe, impose various Lockdowns to minimize the risk of infection but it has affected the life of a woman to a great extent (Biroli et al., 2020). These lockdowns brought the children and parents at home which have short and long-run effects on the women's daily routines. This involves reducing the working women's chances to work efficiently, which increases family tension and family instability (Ruppanner et al., 2018; Buddhapriya, 2009). Biroli et al. (2020) found gender discrepancies in the responsibility of sharing household tasks. Carlson et al. (2020) found that parents felt in the increase of childcare pressure (from 50\%-60\%) and household tasks (38\% to 53\%). Division of the household work affects the women's wellbeing and tensions which results in the overall dissatisfaction towards a prosperous life. WHO found issued various guidelines in the European countries and the USA, to help the women who are stuck at home and faces various problems due to pandemic's and lockdown (Gautam et al. 2020).

\subsection{Changes in professional life: Virtual teaching and its effects}

The sudden shift to the "online portal" due to pandemic situation impose more stress and workloads on the teachers and staff members who try to maintain a work-life balance in addition to teaching, research, and service obligations (Rapanta et al., 2020; Houlden and Veletsianos, 2020). This immediate situation impacts the teacher with all backgrounds and ages because they had to prepare for virtual teaching which entails technical challenges and the absence of technical support (Hodges 
et al., 2020). The highest affected domain is higher education which suffers from the shortage of pedagogical content knowledge (Shulman, 1987) including online platforms, tools, and organizing workflows that enrich the online teaching impact. Around the world, teachers had been reported an increase in the level of stress and anxiety due to the shifting of teaching to the online mode (ibid. 2020).

The major factors that are affecting the teacher's dissatisfaction include discomfort, feeling lost, and experiencing doubt and worry (Flamholtz and Randle 2008, Ibrahim et al. 2013). Other factors that affect the teacher's resistance to accepting change include teacher's stress, fatigue, mental exhaustion which affects the performance and satisfaction level (Margolis and Nagel, 2006). Apart from these challenges, the responsibility of housework and child care has been defined as women's work which generates the need for work-life balance (Yun et al. 2019). Organizations had a lot of expectations from the working professional including women who work hard to prove themselves competent so as they can fit in the social sphere. If the woman fails to maintain the balance, Men oriented world makes women realize that she does not fit in the organizational structure (Stivers, 2002). Working mothers have more responsibility towards their childcare as compared to men (Fox et al., 2011). This increased burden affects the work outcomes and efficiency related to higher education particularly related to teaching, research, publications, and project grant (Jung, 2020). Therefore, lockdown caused by the pandemic produces negative effects on the females related to higher education including scientists, researchers, teachers, and academicians.

\subsection{Mental and psychological wellbeing}

Psychological well-being refers to the extent to which individuals experience positive emotions in life affected due to relationships with personal growth, the objective in life, social pressures, etc. Situational factors such as stressful events, traumatic experiences affect the individual's mood and anxiety disorders (Gladstone et al., 2012). The spread of Pandemic diseases such as the COVID-19 crisis made the people confined to their homes with uncertain effects and tension related to the financial, health, and economic insecurity resulting in the scare and grief period for everyone. This crisis scenario leads to domestic violence, women's reproductive health care, maternal and child health (Bahn et al., 2020). Biroli et al. (2020) found that couples who quarrel over the household distribution and childcare responsibilities have a strong effect on their mental wellbeing. Life satisfaction is negatively related to the changes in the childcare division. Women take more tensions as compared to men in the context of managing household activities such as grocery duties, riskseeking behavior, and cooperation.

In addition to this, working on virtual platforms affects the psychological wellbeing of the employees (Mulki \& Jaramillo, 2011). Workplace interactions among the employees help them to share their problems, enable coordination and cooperation (Cooper \& Kurland, 2002). In the present scenario when organizations force the academicians to adopt WFH which commences the psychological impact of the virtual work environments. This stress leads to unfavorable effects on the learning and 
psychological health of the students and teachers (Sahu, 2020). A female teacher who has various other responsibilities and higher expectations from the employer regarding the effectiveness of the online teaching patterns develops a sense of dissatisfaction among themselves. Online classes that involve various ICT tools and new portals or apps are not so easy to learn and so handy that everyone feels comfortable while using these tools. This brings anxiety, consciousness, and depression among female teachers. Henceforth, in such a male dominating society, it becomes crucial for the females either to create a work-life balance or they are required to leave the job.

\section{Methods}

\subsection{Instrument: Semi-structured interview}

A structured interview comprises of 30 questions related to three dimensions i.e. ten questions on social and personal life (UN Women Rapid Assessment Survey Questionnaire, 2020), ten questions on professional life \& financial component (Alves et al., 2021; Duraku and Hoxha; 2020) and finally ten questions on the psychological and emotional well being of a woman (Cohen, 1994). After preparing the sample questions, they were sent to the three experts for analyzing their accuracy. For assuring the credibility of questions, the opinion of the expert is used as pretesting method (Olson, 2010). The experts selected for the study consists of three female academicians having experience of more than 5 years, four women corporate with experience of 10 years, and two research scholars. These numbers of experts are sufficient as per Olson (2010). Based on the expert's suggestion and feedback, some sample questions were revised for achieving the research objective (Appendix), and the rest questions examine the respondent's demographic profile.

\subsection{Data collection procedure}

A qualitative research method is employed in this study to explore the triple bottom burden on women due to COVID-19 changes that happened in personal and professional life. To understand the homogenous population thought's, opinions, beliefs, and attitudes for a particular topic, qualitative studies such as focused group discussions and in-depth interviews are generally used (Vindrola-Padros et al. 2020). The psychological responses of the respondents depend upon the social and cultural factors of society that keep on changing with time (Sorokin, 2017). To examine the problem in-depth, participants selected for the study consist of a total of 17 teachers including 5 primary teachers and 4 Secondary teachers employed with schools. Also, 8 assistant professors working with private universities and colleges were included for structured interviews. All the participants have a minimum of 10 years of teaching experience. Participants were employed with educational institutions spread across the state of Uttar Pradesh such as Noida, Varanasi, Mathura, Agra, Lucknow, and Kanpur. 
Lockdown in India was announced in four phases i.e. phase 1- (24 March - 14 April), Phase 2 (15 April - 3 May), Phase 3 (4-17 May), and Phase 4 (18-31 May). Data collected started during phase 4 i.e. 11-17 may, 2020. This period is perfect for data collection as Indians have already experienced 47 days of complete lockdown. Females set up their daily routine by incorporating environmental and social changes. They were not allowed to go out, maids were not coming, all family members were staying at home, and virtual learning had already started. Thus, this period is appropriate for understanding the experience of the working females how they maintain work-life balance along with personal and professional challenges. The respondents included in the study were contacted on telephone or zoom app meeting where they were asked questions for approximately 25-30 min. Face-to-face or personal interviews are not possible at this period due to lockdown. Further, permission was also to record the conversations but some participants did not permit to record, so information was written in those cases.

The systematic procedure for the qualitative data analysis was obtained from the in-depth interviews; the data was reduced into the codes by refining it (Corbin \& Strauss, 1990). In the initial set, the data set obtained from the three categories of teachers was separated into primary, secondary, and higher education teachers. Next, the obtained data was read again and again to understand the impact of the burden on the women's life. MAXQDA version 20, computer-assisted software program (Kuckartz \& Rädiker, 2019), distinct thoughts had been analyzed and reduced into informative short paragraphs. The data had been coded into various segments and these were named based on the content they contain. Table 2, provides the details about the code system including open code, subcode, and code segments from the transcript.

\subsection{Ethical issues \& participants details}

In qualitative research, respondents feel concerned about their identity and want to make it confidential so that they can freely express their views, feelings, and opinions. Therefore, respondents' identity is maintained private and they are categorized according to the teaching segment they belong to (Malhotra \& Das, 2008). The demographic details are presented in Table 1. All the respondents are females of which 5 teachers belong to the age group of 25-34 years and the other 6 teachers belong to the age group of 35-44 years and above 45 years. Eight females have completed their Ph.D., 4 completed their post-graduation, and the remaining have completed their graduation.

\subsection{Reliability and validity}

To check the reliability and validity, Lincoln and Guba (1991) establish four benchmarks which are truth value, applicability, consistency, and neutrality. The combination of case studies, audio-video recordings, document analysis enhances the reliability and validity of a study (Patton, 2002; Yin, 2009). Johnson (1997) defines various methods to promote the research validity and reliability for the qualitative 
Table 1 Characteristics details

\begin{tabular}{lll}
\hline Demographic Characteristics & Measures & Frequency \\
\hline Teacher category & Primary school teacher (p1) & 5 \\
& High school teacher(p2) & 4 \\
& College or university Teacher(p3) & 8 \\
Age & 25-34 years & 5 \\
& $35-44$ years & 6 \\
Qualification & Above 45 years & 6 \\
& Graduation & 5 \\
City & Post graduation & 4 \\
& Ph.D & 8 \\
& Noida & 3 \\
& Varanasi & 3 \\
& Mathura & 3 \\
Experience (Years) & Lucknow & 2 \\
& Kanpur & 3 \\
& Agra & 3 \\
& 10 years & 5 \\
& $11-12$ years & 3 \\
& $13-14$ years & 3 \\
& 15 years & 3 \\
\hline
\end{tabular}

research, one of which method is "Participant Feedback". Lo (2014) and Kornbluh (2015) recommended participant's feedback and check method for assessing and enhancing validity and credibility in qualitative research. Therefore, concluded data and interpretation were discussed and send to the actual participants during October-2020- November 2020.

\section{Results}

The results of the in depth interview are presented in Table 2 along with the major factors, their major codes and sub codes.

\subsection{Environment and social changes}

\subsubsection{Modification in daily task management}

A clear-cut difference in the working hours has been found from the data, where higher education teachers felt that they were experienced extended and long working hours. The time extension might be due to learning the new teaching platforms, making the notes according to virtual platforms, taking the lectures online along managing other household chores. They also agreed that higher education offered some flexibility in 
Table 2 Description of codes

\begin{tabular}{|c|c|c|c|}
\hline & Open Code & Sub Code & Coded Segment \\
\hline \multirow[t]{5}{*}{$\begin{array}{l}\text { Environment and } \\
\text { social changes }\end{array}$} & \multirow[t]{3}{*}{$\begin{array}{l}\text { Modification } \\
\text { in daily task } \\
\text { management }\end{array}$} & Extended hours & $\begin{array}{l}\text { "There is an increase in the working hours.... I start } \\
\text { my work at } 9 \text { am or } 10 \text { am and sometimes it gets } \\
\text { extended to longer hours" (P3 } n=1 \text { ) } \\
\text { "Due to house-related work and shifting to the virtual } \\
\text { system I need time to learn these technology- } \\
\text { related systems... which make to work for extended } \\
\text { hours"(P3 } n=5)\end{array}$ \\
\hline & & $\begin{array}{l}\text { Flexible working } \\
\text { hours }\end{array}$ & $\begin{array}{l}\text { "Due to lockdown, there is mismanagement in daily } \\
\text { schedules which leads to working hours at different } \\
\text { period of times" (P3 } n=1) \\
\text { "The classes time are fixed rest every task is shifted to } \\
\text { other time and family support make it more flexible" } \\
\text { (P3 } n=1)\end{array}$ \\
\hline & & $\begin{array}{l}\text { Reduced working } \\
\text { hours }\end{array}$ & $\begin{array}{l}\text { "During lockdown and closer of schools and colleges } \\
\text { reduced my working hours" (P1 } n=5) \\
\text { "I think virtual teaching platforms are not for } \\
\text { school students and thus my working hours } \\
\text { are reduced" (P2 } n=4)\end{array}$ \\
\hline & \multirow[t]{2}{*}{ Productivity } & $\begin{array}{l}\text { Reduced produc- } \\
\text { tivity }\end{array}$ & $\begin{array}{l}\text { "Due to work at home option, my productivity towards } \\
\text { my job get reduced" (P1 } n=5, \mathrm{P} 2 n=3, \mathrm{P} 3 n=6)\end{array}$ \\
\hline & & No motivation & $\begin{array}{l}\text { "I feel no motivation to work for my career develop- } \\
\text { ment" (P2 } n=1 \text { P3 } n=2)\end{array}$ \\
\hline \multirow[t]{9}{*}{$\begin{array}{l}\text { Changes in Personal } \\
\text { \& professional life }\end{array}$} & \multirow[t]{3}{*}{$\begin{array}{l}\text { Changes due to } \\
\text { virtual teaching }\end{array}$} & More family time & $\begin{array}{l}\text { "My attention towards my family got increased due to } \\
\text { lockdown, absence of home caretakers and not going } \\
\text { to school or college"(P1 } n=3, \mathrm{P} 2 n=2, \mathrm{P} 3 n=2)\end{array}$ \\
\hline & & Easy to manage & $\begin{array}{l}\text { "There is no hurry that I need to get ready and go to } \\
\text { college or school" (P1 } n=1, \mathrm{P} 2 n=1, \mathrm{P} 3 n=2) \\
\text { "Work from home makes gives me better option to man- } \\
\text { age official work at a different time" (P3 } n=2)\end{array}$ \\
\hline & & Save cost & $\begin{array}{l}\text { "My traveling cost incurred on auto, bus or self convey- } \\
\text { ance get reduced of a great extent" (P1 } n=1, \mathrm{P} 2 n=1 \text {, } \\
\text { P3 } n=2)\end{array}$ \\
\hline & \multirow[t]{4}{*}{$\begin{array}{l}\text { Technology nega- } \\
\text { tive effects }\end{array}$} & Feel like robot & $\begin{array}{l}\text { "Teaching on the virtual platform gives a feeling I am } \\
\text { teaching to a computer" (P1 n=3, P2 } n=1, \mathrm{P} 3 n=2)\end{array}$ \\
\hline & & $\begin{array}{l}\text { Student non } \\
\text { participation }\end{array}$ & $\begin{array}{l}\text { "Virtual classes do not have student participation" } \\
\text { "Students feel disconnected with the online class" (P1 } \\
n=1, \mathrm{P} 3 n=2) \\
\text { "Student tend to avoid online class" (P1 } n=1, \mathrm{P} 2 n=1 \text {, } \\
\text { P3 } n=1)\end{array}$ \\
\hline & & Less interesting & $\begin{array}{l}\text { "Many students feel that online classes are less interest- } \\
\text { ing" (P1 } n=2, \mathrm{P} 3 n=1)\end{array}$ \\
\hline & & $\begin{array}{l}\text { One side com- } \\
\text { munication }\end{array}$ & $\begin{array}{l}\text { "Both me and my students feel that virtual platform } \\
\text { is one-way communication" (P1 } n=2, \mathrm{P} 2 n=1, \mathrm{P} 3 \\
n=1) \\
\text { "Online classes don't have a personal feel" (P1 } n=1, \mathrm{P} 2 \\
n=1, \mathrm{P} 3 n=1)\end{array}$ \\
\hline & \multirow[t]{2}{*}{ Changes in roles } & Major changes & $\begin{array}{l}\text { "My responsibility such as household work, childcare, } \\
\text { and elderly care has changed my role" (P1 } n=2, \mathrm{P} 2 \\
n=2, \mathrm{P} 3 n=5)\end{array}$ \\
\hline & & Specific changes & $\begin{array}{l}\text { "Some area i.e. professional lifestyle got changed and } \\
\text { make me change in my life" (P1 } n=3, \mathrm{P} 2 n=2, \mathrm{P} 3 \\
n=3)\end{array}$ \\
\hline
\end{tabular}


Table 2 (continued)

\begin{tabular}{|c|c|c|c|}
\hline & Open Code & Sub Code & Coded Segment \\
\hline \multirow[t]{6}{*}{$\begin{array}{l}\text { Mental and Psycho- } \\
\text { logical wellbeing }\end{array}$} & \multirow[t]{3}{*}{$\begin{array}{l}\text { Psychological } \\
\text { effects }\end{array}$} & $\begin{array}{l}\text { Makes nervous \& } \\
\text { confused }\end{array}$ & $\begin{array}{l}\text { "I get confused and nervous when sudden things arrive } \\
\text { to manage"( } 11 n=0, \mathrm{P} 2 \mathrm{n}=2, \mathrm{P} 3 n=2)\end{array}$ \\
\hline & & $\begin{array}{l}\text { Unable to control } \\
\text { things }\end{array}$ & $\begin{array}{l}\text { "Overpressure of thinks makes me unable to control the } \\
\text { things" (P1 } n=2, \mathrm{P} 2 n=1, \mathrm{P} 3 n=3)\end{array}$ \\
\hline & & $\begin{array}{l}\text { Can't manage } \\
\text { effectively }\end{array}$ & $\begin{array}{l}\text { "Overstress results in mismanagement of things" (P1 } \\
n=3, \mathrm{P} 2 n=1, \mathrm{P} 3 n=3)\end{array}$ \\
\hline & \multirow[t]{3}{*}{ Emotional effects } & Anger & $\begin{array}{l}\text { "I express my anger on my family members or friends" } \\
\text { (P1 } n=1, \mathrm{P} 2 n=1, \mathrm{P} 3 n=1)\end{array}$ \\
\hline & & Irritated & $\begin{array}{l}\text { "Situations due to Covid-19, make me irritated) (P1 } \\
\quad n=2, \mathrm{P} 2 n=2, \mathrm{P} 3 n=4)\end{array}$ \\
\hline & & Pissed off & $\begin{array}{l}\text { "Sometimes I felt pissed off" (P1 } n=2, \mathrm{P} 2 n=1, \mathrm{P} 3 \\
n=3)\end{array}$ \\
\hline
\end{tabular}

$\mathrm{P} 1=5$ primary teachers, $\mathrm{P} 2=4$ Secondary teachers and $\mathrm{P} 3=8$ Assistant Professors

working by taking or schedule the lectures according to your convenience. Moreover, some teachers told me that they were asked to make the video and upload it on the college or university portals so that students can do self-study. On the contrary primary and secondary school teachers felt that the temporary closure of schools had reduced their working hours.

\subsubsection{Productivity}

All the primary school teachers felt that locking at home and increased home burden had reduced their creativity and affected their productivity. Primary teaching requires a lot of creativity and new methods by which they can involve kids with them. For creative thinking, they had no time to think about that. The same opinion was given by the primary and higher education teachers who felt that their productivity towards jobs gets reduced and they were feeling irritated. This brought a negative feeling and reluctance to work for career advancement. Many teachers reported that they felt no motivation towards working.

\subsection{Changes in personal \& professional life}

\subsubsection{Advantages of virtual teaching}

All the female teachers agreed that COVID 19 and its effect such as lockdown make a dynamic change in their daily routines. Shifting teaching from offline to online portals makes the teachers to "work from home" mode that allows them to spend more time with their family. The maid was not coming but this increase the value of time spends by teachers with their families which was absent when everyone was going to college or office. Moreover, flexibility had come to their life, they don't have to wake up early 
and reach college or school on time. This also saves the little cost that was spent on transportation and all.

\subsubsection{Technology negative effects}

Though virtual teaching has facilitated the teachers, still, it has a dark shade that affects the teachers as well as students. Teachers agreed that online teaching has less student participation and sometimes they felt like they are teaching to themselves. Teachers discussed that virtual teaching along with involvement with other household tasks makes them feel like robots. Some university teachers told that when they tried to investigate the reasons for less student participation. The students explained that they found the online class boring and less interesting. Whereas some students mentioned that they felt fatigued when sitting on the computer for $4-5 \mathrm{~h}$ a day. They told that offline classes involve the personal touch which is absent in online classes.

\subsubsection{Changes in roles}

Nearly, all the teachers belonging to any teaching department agreed that virtual teaching and lockdown had brought various changes in their lifestyle and role played by them in their daily lifestyle. All the teachers had to devote extra time in their home for extra care and necessary precautions required for their children and elders due to fear of infections. The change in professional lifestyle brought major changes in their teaching pedagogy in which their effectiveness towards teaching is dependent upon the internet and other platforms involved in taking online classes.

\subsection{Mental and psychological wellbeing}

\subsubsection{Psychological effects}

Secondary school teachers and assistant professors mentioned that due to unplanned and sudden arrival of tasks make them confused and nervous. Teachers mentioned that due to over pressure, management of various things become difficult and cumbersome. As teachers were busy in managing their daily lives that has increased responsibilities, more work life challenges creates more confusions and emerged as a source of stress. Nearly, all the teachers reported that due to the stress, mismanagement of things happens that results in more problems. This mismanagement becomes a major hurdle in managing their work life balance.

\subsubsection{Emotional effects}

Teachers agreed that they express their irritation and anger on their family members. Straus et al.(1998) reported that parent displays their physically or psychologically aggressive behavior toward their children. Due to challenging times of pandemic, behavioral and psychosocial changes are reported by teachers that include aggression and irritation. Teachers reported that sometimes, when situation becomes out of 
control, they feel pissed off. These findings are aligned with Petrakova et al. (2021) that discussed; cause of the stress among the teachers is due to new work-fromhome setup and changes in the work-life balance. Liu and Doan (2020) expressed that empathy should be present among family members and cooperate with each other so that difficult time can be passed with support of each other.

\section{Discussion}

The covid-19 pandemic has introduced an exceptional global survival challenge for mankind. This pandemic brought a significant change in society, environment, economy, political that is affecting the daily routines and work-life balance (Petrakova et al., 2021). The present paper explores the triple burden effect on the female teachers due to the COVID-19 pandemic. The study is an extension of the previous studies undergoing the investigation of pandemic and epidemic effects on women's mental, psychological, health, and stress levels. Dos Santos et al. (2016) reported that in cases of previous epidemic and chronic diseases such as Zika, pregnant women in Brazil and Puerto Rico expressed high levels of stress, anxiety, and depression whether they are infected with Zika or not. Hanson et al. (2016) found that Liberian women may be at high infection risk of Ebola due to traditional gender roles such as taking care of sick people, washing and cleaning household items like clothing and dishes, which may be contaminated by the virus. Brooks et al. (2015) found that a high workload and long working hours when resources are limited due to disaster leaves a negative psychological impact.

The findings of the study identified the prominent reasons for psychological and mental stress for female teachers. The study found that increased family obligations and responsibilities brought important changes in social and environmental setup. In a country such as India, where household tasks are meant to be associated with the "females only" has increased due to the absence of home-maids and family members staying at home. It has become a social stigma and gender roles are defined by "stereotypes" that portray women as weak contenders. This means men meant to stay away from the kitchen and do not helping in raising their children. Biroli et al. (2020) reported that the absence of childcare facilities imposes more pressure on working mothers when responsibility is not shared by fathers. Besides, domestic violence has reached new heights, and data obtained worldwide clearly explained that women are meant to be a soft target (Beland et al., 2020). This means that changes should be brought in home culture and work culture, focusing on creating a balance between work done by women (Folbre, 2017; GrossbardSchectman and Grossbard-Shechtman, 2019).

Findings reveal that stress was exacerbated due to the introduction of online teaching, technology anxiety due to unawareness of the use of online teaching applications such as zoom, lack of technical and informational resources, varying working hours, and resistance from the student's side. UNESCO (2020) found that inexperience and lack of preparation of teachers and parents to support children in 
online teaching impacted the learning needs of the students. Countries worldwide are adopting innovative online platforms for online teaching methods and knowledge sharing has brought various concerns such as increased stress and anxiety among the teaching community (UNESCO, March 2020). The study highlighted that female teacher agreed that new teaching platforms are challenging and learning about these new platforms is difficult in such a negative atmosphere. COVID- 19 impacted the daily schedule and difficulty increases when learning of ICT blended techniques for virtual teaching becomes necessitate. This finding is similar to previous studies. Teachers felt a lot of challenges to become adaptable to new methods of teaching which involves technological complexity, literacy, and competency (Rahman \& Abdullah, 2018). These emerging challenges reduced the teacher's and students' attention toward effective learning. Talidong and Toquero (2020) found that the teaching community by adhering to the work from home guidelines is experiencing anxiety in this pandemic situation.

The study reported that female educationists are concerned about financial stress caused by lockdown and salary deduction; future planning, and healthrelated issues. These findings are affecting the teacher's psychological and emotional effects during the challenging times of COVID-19. This result is similar to a study conducted by Gopal et al. (2020); Limcaoco et al., 2020; Moccia et al., 2020) that women found to be suffering from stress, anxiety, and depression. Brug et al. (2004) found that during SARS (Severe acute respiratory syndrome) in the Netherlands, women were observed to be at high risk of infection. All the teachers reported negative and unpleasant experiences such as nervousness, confusion, anger, irritation, resulting in the mismanagement of various things. The main reasons might be due to social distancing (Ammerman et al., 2020); overwork pressure, management of extra home-related tasks (Power 2020); use of new technology (Rasheed et al., 2020), household, and job-related tensions (Biroli et al. 2020). Further, Goswami and Narah (2021) found that a positive correlation between "perceived stress and depression" predicting the women are inclined towards depression during these difficult times of pandemic. Despite negative results, a pessimistic view focuses that due to lockdown and staying at home; female teachers agreed that they can spend valuable time with their family members. They have no hurry to report at school or college, manage the transport, and prepare the meals early for everyone. The work from home brought some flexibility to their life.

\section{Implications of research}

COVID-19 has brought drastic changes in the lifestyle and working patterns of the people worldwide and impacted them worldwide. It created fear, anxiety, and depression; stress among the people especially those who lost their loved ones in this pandemic. People of every professional are worried about their safety and future. In this time due to the shifting of offline teaching to the online teaching mode, new challenges emerge along with creating work-life balance. The study has social implications where the study is providing insights about the life of 
female teachers that how she manage his home. Teachers devote long hours to learning the new platforms and making the videos, reading material, and presentations ready for their students. The study provides important insights into educational institutes that how teachers are getting themselves more acquainted with the latest teaching pedagogy and getting well versed with it. The study also provides some output to the government that how in such an educated society, social stigma regarding home management and gender roles are still defined. The women still meant to manage and tolerate everything. Therefore, the government should devise some policies or awareness programs that can change the mindset of modern society so that they can understand the real meaning of being educated and modernization.

\section{Limitation and future directions}

The present research suffers from some limitations. Future research can be carried out on the females belonging to a different profession such as doctors, managers, bank officials, etc. to access their life and how they are handling the work-life balance and burden of daily life. A comparative study can be done to found the difference in the way of living of men and women when everyone's life is affected by the pandemic. Adoption of WFH affected the productivity of the employees; therefore, smart techniques should be invented which helps them to become more flexible towards the teaching methods which is easy to learn.

\section{Conclusion}

A drastic and non-reversible consequence has been observed on the economic, psychological, and social, due to lockdown imposed as safety measured during the pandemic. Pandemic brought magnanimous physical and economic outcomes on human lives that obtain higher attention. Still, the impacts of COVID19 on the psychological and emotional well-being of working females are often less gratified. Although, psychological and emotional health is equally important along with physical health, thus there exists a rift in understanding the pandemic effects on psychological and emotional health. Henceforth, the present study addresses this research gap and attempted to link the association between environment and social changes; Changes in Personal \& professional life \& the Mental and Psychological wellbeing of a female in the education sector. India, as an important emerging economy seems to be comprised of a population that requires attention because women's distress adds fuel to Mental and Psychological wellbeing. Findings reported that female teachers are suffering from worklife balance problems, where covid-19 and lockdown added more problems to their fortune. This outcome is significant for the Indian government that how proper counseling cells could help the women educationists in apprehending the 
psychological repercussions. The government can use study findings in formulating a future proper strategy for handling the violence and reducing the gender gap which is still deeply rooted in the country's various regions.

\section{Appendix}

\section{Questionnaire}

\section{Part A}

Q1. As a result of COVID-19, has the number of hours devoted to household activities changed?

Q2. Since the spread of COVID-19, in which activity do you spend the most time?

1. Cooking and serving meals

2. Cleaning (e.g. clothes, household)

3. Minding children while doing other tasks (e.g. paid work)

4. Playing with, talking to, and reading to children

5. Instructing, teaching, training children

6. Caring for children, including feeding, cleaning, physical care

7. Assisting older/sick/disabled adults with medical care, feeding, cleaning, physical care

8. Assisting older/sick/disabled adults with administration and accounts

9. Affective/emotional support for adult family members

Q3. Does your partner help you with household chores and caring for your family?

Q4. Does your child help you with household chores and caring for your family?

Q5. Does your other family member help you with household chores and caring for your family?

Q6. Do you allow your domestic worker/babysitter/nurse to stay with you?

Q7. Do you feel your work schedule extended to longer working hours?

Q8. Do you feel your work is reduced to shorter working hours?

Q9. Do you think lockdown results in Flexible working hours?

Q10. Do you felt difficulty in meeting both the end meet? 


\section{Part B}

Q1. Do you feel like coming of COVID-19 brought maximum changes in your roles?

Q2. Do you feel shifting to virtual learning mode changed your working style?

Q3. Do you feel getting involved in multiple tasks reduced your efficiency?

Q4. Do you feel motivated to work from home mode?

Q5. Do you think opting for "work from home mode" is an easy method?

Q6. Do you feel by doing work from home it is easy to manage home and family?

Q7. Do you feel by doing work from home saves cost and time?

Q8. Do you feel virtual teaching is not an effective method of teaching?

Q9. Do you think in online teaching student participation is reduced?

Q10. What do you think you work like Robert in work from home mode?

\section{Part C}

Q1. During covid-19, how often have you been upset because of something that happened unexpectedly?

Q2. Do you feel you are unable to control things?

Q3. Managing work, home, and new technology challenges how much you felt nervous and "stressed"?

Q4. How much you felt confident in managing personal and professional things?

Q5. Do you felt things are going out of your way?

Q6. Do you felt you cannot cope up and manage things effectively?

Q7. During covid-19 do you felt irritated?

Q8. Do you felt pissed off?

Q9. Do you express your anger to your family members or friends?

Q10. Do you felt that difficulties are increasing and can't be managed?

\section{Part D}

\begin{tabular}{|c|c|c|c|c|c|}
\hline $\begin{array}{l}\text { Teacher cat- } \\
\text { egory }\end{array}$ & $\begin{array}{l}\text { a) Primary } \\
\text { school } \\
\text { teacher }\end{array}$ & $\begin{array}{l}\text { b) High school } \\
\text { teacher }\end{array}$ & $\begin{array}{l}\text { c) College or } \\
\text { university } \\
\text { Teacher }\end{array}$ & & \\
\hline Age: & a) 25-34 years & b)35-44 years & $\begin{array}{l}\text { c) Above } \\
45 \text { years }\end{array}$ & & \\
\hline Qualification & Graduation & $\begin{array}{l}\text { a) Post gradu- } \\
\text { ation }\end{array}$ & b) Ph.D. & & \\
\hline City: & a) Noida b) & Varanasi & c) Mathura & d) Lucknow e) Kanpur & f) Agra \\
\hline $\begin{array}{l}\text { Experience } \\
\text { (Years): }\end{array}$ & a) 10 years & b)11-12 years & c) $13-14$ years & d) 15 years & \\
\hline
\end{tabular}




\section{References}

Alves, R., Lopes, T., \& Precioso, J. (2021). Teachers' well-being in times of Covid-19 pandemic: Factors that explain professional well-being. IJERI: International Journal of Educational Research and Innovation, 15, 203-217

Aryee, S., Srinivas, E. S., \& Tan, H. H. (2005). Rhythms of life: Antecedents and outcomes of workfamily balance in employed parents. Journal of Applied Psychology, 90(1), 132-146

Aycan, Z. (2004). Key success factors for women in management in Turkey. Applied Psychology: An International Review., 53(3), 453-477

Bahn, K., Cohen, J., \& van der Meulen Rodgers, Y. (2020). A feminist perspective on COVID-19 and the value of care work globally. Gender, Work and Organization, 27(5), 695-699

Bao, W. (2020). COVID -19 and online teaching in higher education: A case study of Peking University. Human Behavior and Emerging Technologies, 2(2), 113-115

Beland, Louis-Philippe, Abel Brodeur, Joanne Haddad, and Derek Mikola. (2020). Covid-19, family stress and domestic violence: Remote work, isolation and bargaining power. No. 571. GLO Discussion Paper

Biroli, P., Bosworth, S., Della Giusta, M., Di Girolamo, A., Jaworska, S., \&, Vollen, J. (2020). Family life in lockdown. IZA Discussion Paper No. 13398

Bradshaw, S. (2015). Engendering development and disasters. Disasters, 39(1), 54-75

Brancaccio, M., Mennitti, C., Gentile, A., Correale, L., Buzzachera, C. F., Ferraris, C., ... \& Scudiero, O. (2021). Effects of the covid-19 pandemic on job activity, dietary behaviours and physical activity habits of university population of Naples, federico ii-Italy. International Journal of Environmental Research and Public Health, 18(4), 1502

Brooks, S. K., Dunn, R., Sage, C. A. M., Amlôt, R., Greenberg, N., \& Rubin, G. J. (2015). Risk and resilience factors affecting the psychological wellbeing of individuals deployed in humanitarian relief roles after a disaster. Journal of Mental Health, 24(6), 385-413. https://doi.org/10.3109/09638237. 2015.1057334

Brown, M. G. (2016). Blended instructional practice: A review of the empirical literature on instructors' adoption and use of online tools in face-to-face teaching. The Internet and Higher Education, 31, $1-10$

Brug, J., Aro, A. R., Oenema, A., De Zwart, O., Richardus, J. H., \& Bishop, G. D. (2004). SARS risk perception, knowledge, precautions, and information sources, The Netherlands. Emerging Infectious Diseases, 10(8), 1486

Buddhapriya, S. (2009). Work-family challenges and their impact on career decisions: A study on Indian women professionals. Vikalpa: The Journal of Decision Makers, 34(1), 31-45

Carlson, D. L., Petts, R., \& Pepin, J. R. (2020). US couples' divisions of housework and childcare during COVID-19 pandemic. SocArXiv. https://doi.org/10.31235/osf.io/jy8fn

Chen, P.; Mao, L.; Nassis, G.P.; Harmer, P.; Ainsworth, B.E.; Lif, E. (2020). Coronavirus Disease (COVID-19): The need to maintain regular physical activity while taking precautions. Journal of Sport and Health Science, 9, 103-104

Cohen, S., Kamarck, T., \& Mermelstein, R. (1994). Perceived stress scale. Measuring stress: A guide for health and social scientists, 10(2), 1-2

Cooper, C. D., \& Kurland, N. B. (2002). Telecommuting, professional isolation, and employee development in public and private organizations. Journal of Organizational Behavior, 23, 511-532. https:// doi.org/10.1002/job.145

Corbin, J. M., \& Strauss, A. (1990). Grounded theory research: Procedures, canons, and evaluative criteria. Qualitative Sociology, 13(1), 3-21

Dang, H. A. H., \& Nguyen, C. V. (2021). Gender inequality during the COVID-19 pandemic: Income, expenditure, savings, and job loss. World Development, 140, 105296

Deshpande, A. (2020). How India's lockdown has put women at a greater disadvantage, Retrieved from: https://scroll.in/article/957787/how-indias-lockdown-has-put-women-in-middle-class-homes-at-agreater-disadvantage

Dos Santos Oliveira, S. J., de Melo, E. S., Reinheimer, D. M., Gurgel, R. Q., Santos, V. S., Martins-Filho, P. R., et al. (2016). Anxiety, depression, and quality of life in mothers of newborns with microcephaly and presumed congenital Zika virus infection. Archives of Women's Mental Health, 19, 1149-1151 
Dunton, G. F., Do, B., \& Wang, S. D. (2020). Early effects of the COVID-19 pandemic on physical activity and sedentary behavior in children living in the U.S. BMC Public Health, 20, 1351

Duraku, Z. H., \& Hoxha, L. (2020). The impact of COVID-19 on education and on the well-being of teachers, parents, and students: Challenges related to remote (online) learning and opportunities for advancing the quality of education. Retrieved online from https://www.researchgate.net/publication/ 341297812

Flamholtz, E. G., \& Randle, Y. (2008). Leading strategic change. Cambridge University Press

Folbre, N. (2017). The care penalty and gender inequality. The Oxford Handbook of Women and Economy, 1-28

Fox, M. F., Fonseca, C., \& Bao, J. (2011). Work and family conflict in academic science: Patterns and predictors among women and men in research universities. Social Studies of Science, 41(5), 715-735

Gautam, A., Yadav, N., Suri, K., Garg, A., \& Garg, K. (2020). Exploring the socio-economic impact of COVID 19: A case of India. PCI Report Series, New Delhi: Policy Change Initiative, 1-78

Gladstone, J., Dumbrill, G., Leslie, B., Koster, A., Young, M., \& Ismaila, A. (2012). Looking at engagement and outcome from the perspectives of child protection workers and parents. Children and Youth Services Review, 34(1), 112-118

Gopal, A., Sharma, A. J., \& Subramanyam, M. A. (2020). Dynamics of psychological responses to COVID-19 in India: A longitudinal study. PLoS One, 15(10), e0240650

Goswami, K., \& Narah, M. Y. (2021). The effect of COVID-19 on women in north-East India: An intersectionalism perspective. The International Journal of Indian Psychology, 9(1), 759-768

Grossbard-Schectman, S., \& Grossbard-Shechtman, S. (2019). On the economics of marriage. Routledge

Hanson, J., Decosimo, A., \& Quinn, M. (2016). Diminished quality of life among women affected by Ebola. Journal of Social, Behavioral and Health Sciences, 10(1), 11

Hebert, L. E., Bansal, S., Lee, S. Y., Yan, S., Akinola, M., Rhyne, M., Menendez, A., \& Gilliam, M. (2020). Understanding young women's experiences of gender inequality in Lucknow, Uttar Pradesh through story circles. International Journal of Adolescence and Youth, 25(1), 1-11. https://doi.org/ 10.1080/02673843.2019.1568888

Hodges, C., Moore, S., Lockee, B., Trust, T., \& Bond, A. (2020). The difference between emergency remote teaching and online learning. Educause Review, 27(1), 1-9

Hooda, D. S. (2021). Gender inequality in India: Status and determinants. International Journal of Social Science and Economic Research, 6(3), 1054-1070

Houlden, S., \& Veletsianos, G. (2020). Coronavirus pushes universities to switch to online classes - but are they ready?. The Conversation, 12 March. https://theconversation.com/coronaviruspushes-unive rsities-toswitch-to-online-classes-but-arethey-ready-132728

House, D. N., Hartog, Den, Hanges, R. J., Ruiz-Quintanilla, P. J., Dorfman, S. A., Abdalla, P. W., \& Zhou, J. (1999). Culture specific and cross-culturally generalizable implicit leadership theories: Are attributes of charismatic/transformational leadership universally endorsed? The Leadership Quarterly, 10(2), 219-256

Ibrahim, A., Al-Kaabi, A., \& El-Zaatari, W. (2013). Teacher resistance to educational change in the United Arab Emirates. International Journal of Research Studies in Education, 2(3), 25-36

Johnson, R. B. (1997). Examining the validity structure of qualitative research. Education, 118(2), 282

Jost, J. T., \& Banaji, M. R. (1994). Role of stereotyping in system- justification and the production of false consciousness. British Journal of Social Psychology, 33(1), 1-27

Jung, H. (2020).COVID-19 stay-at-home orders worsen academic scientists' home-life: women experience more difficulties. Available at SSRN 3642732

Kaberia, S. K., \& Muathe, S. M. (2021). Effect of Covid-19 pandemic on performance of women owned micro, small and medium Enterprises in Kenya. International Journal of Social Science Studies, 9(1), 7-21

Kornbluh, M. (2015). Combatting challenges to establishing trustworthiness in qualitative research. Qualitative Research in Psychology, 12, 397-414

Kuckartz, U., \& Rädiker, S. (2019). Analyzing focus group data. In analyzing qualitative data with MAXQDA (pp. 201-217). Springer.

Kumari, A., Ranjan, P., Sharma, K. A., Sahu, A., Bharti, J., Zangmo, R., \& Bhatla, N. (2021). Impact of COVID-19 on psychosocial functioning of peripartum women: A qualitative study comprising focus group discussions and in-depth interviews. International Journal of Gynecology \& Obstetrics, 152(3), 321-327 
Leckie, J. (2016). Development, gender and security in a new millennium. In J. Leckie (Ed.), Development in an insecure and gendered world: The relevance of the Millenium goals (pp. 21-46). Routledge

Lee, J. M., Yoo, S.-S., \& Hong, M. S. (2019). WID, GAD or somewhere Else? A critical analysis of gender in Korea's international education and development. Journal of Contemporary Eastern Asia, 18, 94-123

Limcaoco, R.S.G., Mateos, E.M., Fernandez, J.M., Roncero, C., 2020. Anxiety, worry and perceived stress in the world due to the COVID-19 pandemic, March 2020. Preliminary Results. medRxiv.

Lincoln, Y. S., \& Guba, E. G. (1991). Nat inquiry. Sage Publications

Liu, C. H., \& Doan, S. N. (2020). Psychosocial stress contagion in children and families during the COVID-19 pandemic. Clinical Pediatrics, 59(9-10), 853-855

Liu, Y., Wei, S., \& Xu, J. (2021). COVID-19 and women-led businesses around the world. Finance Research Letters, 102012. https://doi.org/10.1016/j.frl.2021.102012

Lo, C. (2014). Enhancing grounded-ness in realist grounded theory research. Qualitative Psychology, 1, 61-76

Malhotra, N. K., \& Das, S. (2008). Marketing research: An applied orientation. Pearson Education

Margolis, J., \& Nagel, L. (2006). Education reform and the role of administrators in mediating teacher stress. Teacher Education Quarterly, 33(4), 143-159

McLaren, H. J., Wong, K. R., Nguyen, K. N., \& Mahamadachchi, K. N. D. (2020). Covid-19 and women's triple burden: Vignettes from Sri Lanka, Malaysia, Vietnam and Australia. Social Sciences, $9(5), 87$

Moccia, L., Janiri, D., Pepe, M., Dattoli, L., Molinaro, M., De Martin, V., ... \& Di Nicola, M. (2020). Affective temperament, attachment style, and the psychological impact of the COVID- 19 outbreak: an early report on the Italian general population. Brain, Behavior, and Immunity 87, 75-79

Momsen, J. (2019). Gender and Development. Routledge

Moreno, J., \& Shaw, D. (2018). Women's empowerment following disaster: A longitudinal study of social change. Natural Hazards, 92, 205-224

Moser, C. (2012). Gender planning and development: Theory practice and training. Routledge

Mulki, J. P., \& Jaramillo, F. (2011). Ethical reputation and value received: Customer perceptions. International Journal of Bank Marketing, 29(5), 358-372. https://doi.org/10.1108/02652321111152891

Nawaz, F., \& McLaren, H. J. (2016). Silencing the hardship: Bangladeshi women, microfinance and reproductive work. Social Alternatives, 35, 19-25

Olson, K. (2010). An examination of questionnaire evaluation by expert reviewers. Field Meth, 22(4), 295-318

Patton, M. Q. (2002). Qualitative research \& evaluation methods. Sage Publications

Petrakova, A., Kanonire, T., Kulikova, A., \& Orel, E. (2021). Characteristics of teacher stress during distance learning imposed by the COVID-19 Pandemic. Voprosy Obrazovaniyal Educational Studies Moscow, 1, 93-114

Pinola, M. (2020). The 7 biggest remote work challenges (and how to overcome them). Retrieved from: https://zapier.com/blog/remote-work-challenges/

Power, K. (2020). The COVID-19 pandemic has increased the care burden of women and families. Sustainability: Science, Practice and Policy, 16(1), 67-73

Prasad, K., Rao, M., Vaidya, R., Muralidhar, B. (2020). Organizational climate, opportunities, challenges and psychological wellbeing of the remote working employees during COVID-19 pandemic: A general linear model approach with reference to information technology industry in Hyderabad. International Journal of Advanced Research in Engineering and Technology (IJARET), 11(4), 372-389

Priya, N., Abhishek, G., Ravi, V., Aarushi, K., Nizamuddin, K., Dhanashri, B., Shobhana, B., \& Sanjay, K. (2015). Masculinity, intimate partner violence and son preference in India - findings from Uttar Pradesh. International Center for Research on Women

Rahman, M. M., \& Abdullah, N. A. (2018). A personalized group-based recommendation approach for web search in E-learning. IEEE Access, 6, 34166-34178

Rapanta, Chrysi, Luca Botturi, Peter Goodyear, Lourdes Guàrdia, and Marguerite Koole. (2020). Online University teaching during and after the Covid-19 Crisis: Refocusing teacher presence and learning activity. Post digital Science and Education, 1-23

Rasheed, R. A., Kamsin, A., \& Abdullah, N. A. (2020). Challenges in the online component of blended learning: A systematic review. Computers \& Education, 144, 103701

Ravindran, B., \& Baral, R. (2014). Factors affecting the work attitudes of Indian re-entry women in the IT sector. Vikalpa, 39(2), 31-42 
Ruppanner, L., Brandén, M., \& Turunen, J. (2018). Does unequal housework lead to divorce? Evidence from Sweden. Sociology, 52(1), 75-94

Sahu, P. (2020). Closure of universities due to coronavirus disease 2019 (COVID-19): Impact on education and mental health of students and academic staff. Cureus, 12(4)

Sangani, Priyanka. (2020). Coronavirus crisis may fast-forward IT's work-from-home adoption. Retrieved from: https://economictimes.indiatimes.com/tech/ites/coronavirus-crisis-may-fast-forward-its-workfrom-home-adoption/articleshow/74766020.cms?utmsource=contentfinterest\&utm_medium =text\& utm_campaign=cppst

Shaukat, N., Ali, D. M., \& Razzak, J. (2020). Physical and mental health impacts of COVID-19 on healthcare workers: A scoping review. International Journal of Emergency Medicine, 13, 40

Shorey, S. Y., Ng, E. D., \& Chee, C. Y. (2021). Anxiety and depressive symptoms of women in the perinatal period during the COVID-19 pandemic: A systematic review and meta-analysis. Scandinavian Journal of Public Health, 1-11

Shulman, L. (1987). Knowledge and teaching: Foundations of the new reform. Harvard Educational Review, 57, 1-22

Sorokin, P. (2017). Social and cultural dynamics: A study of change in major systems of art, truth, ethics, law and social relationships. Routledge

Stivers, C. (2002). Gender images in public administration: Legitimacy and the administrative state. Sage Publications

Straus, M. A., Hamby, S. L., Finkelhor, D., Moore, D. W., \& Runyan, D. (1998). Identification of child maltreatment with the parent-child conflict tactics scales: Development and psychometric data for a national sample of American parents. Child Abuse \& Neglect, 22, 249-270

Talidong, K. J. B., \& Toquero, C. M. D. (2020). Philippine teachers' practices to deal with anxiety amid COVID-19. Journal of Loss and Trauma, 1-7

Women UN. Impact of COVID-19 on violence against women and girls and service provision: UN Women rapid assessment and findings [UN Women website]. (2020). Retrevied from: https://www. unwomen.org/-/media/headquarters/attachments/sections/library/publications/2020/impact-ofcovid-19-on-violenceagainst-women-and-girls-and-service-provision-en.pdf?la=en \&vs=0

UNESCO. (2020). COVID-19 educational disruption and response. Retrieved from https://en.unesco.org/ themes/education-emergencies/coronavirus-school-closures

Vindrola-Padros, C., Chisnall, G., \& Cooper, S. (2020). Carrying out rapid qualitative research during a pandemic: Emerging lessons from COVID-19. Qualitative Health Research. https://doi.org/10. $1177 / 1049732320951526$

Wheatley, D. (2017). Employee satisfaction and use of flexible working arrangements. Work, Employment and Society, 31(4), 567-585

Yin, R. K. (2009). Case study research: Design and methods. Sage Publications

Yun, J. A., Lee, Y., \& Mastracci, S. (2019). The moderating effect of female managers on job stress and emotional labor for public employees in gendered organizations: Evidence from Korea. Public Personnel Management, 48(4), 535-564

Publisher's note Springer Nature remains neutral with regard to jurisdictional claims in published maps and institutional affiliations. 